\title{
PENGARUH PERSEPSI SISWA TENTANG PENGELOLAAN PEMBELAJARAN DAN MOTIVASI BELAJAR TERHADAP HASIL BELAJAR KELAS XI IPS MATA PELAJARAN EKONOMI DI SMA N 2 SINGARAJA TAHUN 2017
}

\author{
Putu Linda Yani ${ }^{1}$, Anjuman Zukhri², Lulup Endah Tripalupi ${ }^{3}$ \\ Jurusan Pendidikan Ekonomi \\ Universitas Pendidikan Ganesha \\ Singaraja, Indonesia \\ e-mail: lindayani0303@gmail.com ${ }^{1}$, anjuman.zukri.12@yahoo.com² \\ lulup tripalupi@yahoo.com ${ }^{3}$
}

\begin{abstract}
Abstrak
Penelitian ini bertujuan untuk mengetahui pengaruh persepsi siswa tentang pngelolaan pembelajaran, pengaruh motivasi belajar, pengaruh persepsi siswa tentang pengelolaan pembelajaran dan motivasi belajar terhadap hasil belajar siswa kelas XI IPS di SMA N 2 Singaraja. Penelitian ini menggunakan rancangan penelitian kausal. Teknik penentuan sampel yang digunakan adalah stratified random sampling. Data dikumpulkan dengan kuesioner dan dokumentasi yang selanjutnya dianalisis dengan analisis regresi linier berganda dengan menggunakan bantuan SPSS (Statistical Program Sosial Science) versi 16.0. Hasil uji t 6,452 dengan nilai signifikan $0,009<0,05$ menunjukkan adanya pengaruh yang positif antara persepsi siswa tentang pengelolaan pembelajaran terhadap hasil belajar, hasil uji t 2,420 dengan nilai signifikan 0,021 0,05 menunjukkan adanya pengaruh yang positif antara motivasi belajar terhadap hasil belajar, dan hasil uji $F$ 21,106 dengan nilai signifikan 0,036 $<0,05$ menunjukkan adanya pengaruh yang positif secara simultan persepsi siswa tentang pengelolaan pembelajaran dan motivasi belajar terhadap hasil belajar.
\end{abstract}

Kata kunci: persepsi siswa, motivasi belajar, hasil belajar

\section{Abstract}

This study aims to determine, the influence of students 'perceptions of learning management, learning motivation, partially and simultaneously to the student learning outcomes of grade XI IPS students in SMA N 2 Singaraja. This study used a causal research design. Sample determination technique used is stratified random sampling. Data were collected by questionnaire and documentation which then analyzed with multiple linear regression analysis using SPSS (Statistical Program Social Science) version 16.0. Result of $t$ test 6,452 with significant value $0,000<0,05$ show the existence of positive influence between student perceptoin about process of learning manajement to result learn. Result of $t$ test 2,420 with significan value $0,021<0.05$ show a positive influence between learning motivation to learning outcome. Result $F$ test 21,106 with significant $0,036<0,05$ show a positive influence simultaneously berween students perceptions of learning management and motivation on learning outcome.

Keywords: student perception, learning motivation, learning outcomes 


\section{PENDAHULUAN}

Hasil Belajar merupakan muara dari proses pembelajaran yang dapat digunakan oleh guru untuk dijadikan ukuran atau kriteria dalam mencapai suatu tujuan pendidikan. Menurut Slameto (2010:2) "hasil belajar merupakan suatu proses usaha yang dilakukan seseorang untuk memperoleh suatu perubahan tingkah laku yang baru secara keseluruhan, sebagai hasil pengalamannya sendiri dalam interaksi lingkungannya".

Banyak faktor yang mempengaruhi hasil belajar siswa haruslah sangat diperhatikan. Ada dua faktor yang mempengaruhi hasil belajar siswa yaitu faktor internal dan faktor ekternal. Dalam faktor internal (dari dalam diri siswa) tersebut meliputi kemampuan yang dimiliki oleh siswa tersebut, motivasi belajar, minat dan perhatian siswa, sikap dan kebiasaan belajar, ketekunan, sosial ekonomi, dan faktor fisik psikisnya. Sedangkan faktor ekternal (dari luar) adalah kualitas pengajaran, instrumen, model pembelajaran dan lain sebagainya. (Sudjaya, 2002:22).

Menurut Donald (2012:73), "salah satu faktor internal yang mempengaruhi hasil belajar adalah motivasi. Motivasi adalah perubahan energi dalam diri seseorang yang ditandai dengan munculnya feeling dan didahului dengan tanggapan terhadap adanya tujuan". Motivasi juga dapat dikatakan sebagai serangkaian usaha untuk menyediakan kondisi-kondisi tertentu, sehingga seseorang mau dan ingin melaksanakan atau melakukan sesuatu. Motivasi dapat tumbuh dalam diri seseorang setelah di rangsang dari luar. Motivasi dapat menyebabkan terjadinya perubahan energi yang ada pada diri seseorang, sehingga akan berpengaruh terhadap jiwa, perasaan dan emosi, untuk kemudian bertindak atau melakukan sesuatu. Seorang siswa mau belajar karena adanya motivasi untuk belajar karena motivasi adalah motor penggerak yang mendorong seseorang untuk melakukan sesuatu termasuk belajar maka dengan adanya motivasi belajar dari seorang siswa akan mampu meningkatkan hasil ataupun prestasi belajar siswa tersebut. Sehingga jika seorang siswa memiliki motivasi yang tinggi untuk belajar dan aktif dalam mengikuti pembelajaran maka diharapkan hasil belajar yang didapatkan akan tinggi. Namun untuk menumbuhkan motivasi belajar siswa maka harus di dorong oleh orang tua maupun guru disekolah, karena dengan adanya dorongan dari orang tua dan guru maka akan membantu pertumbuhan motivasi siswa untuk belajar dengan baik. Setiap siswa memiliki persepsi berbeda mengenai pembelajaran yang dilakukan setiap persepsi yang dimiliki oleh siswa juga akan membantu bagaimana siswa itu sendiri menerima pembelajaran yang diberikan yang akan menunjang meningkatnya hasil belajar siswa itu sendiri

Setiap orang atau siswa bisa saja memiliki persepsi yang berbeda-beda mengenai suatu hal, obyek, ataupun kejadian meskipun hal, obyek, ataupun kejadian tersebut adalah sama. Hal ini dipengaruhi oleh perbedaan pemahaman terhadap stimulus yang ditangkap sehingga efek yang akan ditimbulkan pada setiap orang akan berbeda. Walgito (2010:99) menyatakan, "persepsi merupakan suatu proses yang didahului oleh proses penginderaan, yaitu merupakanproses diterimanya stimulus oleh individu melalui alat indera atau disebut proses sensoris".

Menurut Sugihartono (2007:8), "persepsi merupakan proses untuk menerjemahkan dan menginterpretasikan stimulus yang masuk ke dalam indera". Perilaku seseorang akan dipengaruhi oleh bagaimana persepsi seseorang mengenai sesuatu. Menurut Slameto (2003:102), "persepsi adalah proses menyangkut masuknya pesan/informasi ke dalam otak manusia". Melalui persepsi, seseorang dapat berhubungan melalui inderanya yaitu indera penglihatan, pendengaran, peraba, perasa, dan pencium dengan lingkungannya secara berkelanjutan.

Adapun faktor-faktor yang mempengaruhi persepsi yang di ungkapkan oleh Miftah (2003:154) adalah sebagai 
berikut.Yang pertama yaitu, faktor internal merupakan faktor yang berasal dari dalam diri seseorang seperti perasaan, sikap dan kepribadian individu, prasangka, keinginan atau harapan, perhatian (fokus), proses belajar, keadaan fisik, gangguan kejiwaan, nilai dan kebutuhan juga minat, dan motivasi. Yang kedua faktor eksternal merupakan faktor yang berasal dari luar diri seseorang seperti latar belakang keluarga, informasi yang diperoleh, pengetahuan dan kebutuhan sekitar, intensitas, ukuran, keberlawanan, pengulangan gerak, hal-hal baru dan familiar atau ketidak asingan suatu objek

Dalam UU No. 20 Tahun 2003, dijelaskan bahwa "pembelajaran adalah proses interaksi peserta didik dengan pendidik dan sumber belajar pada lingkungan belajar". Menurut Sanjaya (2009) pengelolaan pembelajaran adalah sebuah kegiatan untuk mengendalikan aktifitas pembelajaran berdasarkan konsep dan prinsip pembelajaran untuk mencapai tujuan yang telah ditetapkan. Pengelolaan Pembelajaran merupakan proses untuk mencapai tujuan pembelajaran. Tujuan dari pengelolaan pembelajaran adalah untuk menciptakan proses belajar mengajar dengan mudah direncanakan, diorganisasikan, dilaksanakan dan dikendalikan dengan baik sehingga tercapai tujuan pengajaran secara efektif dan efesien. Untuk mencapai tujuan pembelajaran diperlukan proses panjang yang dimulai dengan perencanaan, pengorganisasian dan penilaian. Pengelolaan pembelajaran diawali dengan penentuan strategi dan perencanaan, proses dan diakhiri dengan penilaian. Pelaksanaan pengelolaan pembelajaran dikelas meliputi pengelolaan waktu, pengelolaan media dan pengelolaan kelas.

Pengelolan pembelajaran di kelas yang baik diharapkan mampu meningkatkan hasil belajar siswa, sdengan menggunakan metode pembelajaran yang menarik yang mampu menumbuhkan dan menarik motivasi siswa dalam mengikuti pembelajaran. Menurut Djamarah (2002:195), menyatakan bahwa "pengelolaan pembelajaran dilakukan untuk mencapai tujuan pembelajaran yang efektif dan efesien. Pengelolaan kelas yang dilakukan oleh guru memegang peran penting untuk menanamkan motivasi pada siswa untuk menerima pembelajaran". Dengan adanya pengelolaan pembelajaran dikelas dengan baik maka motivasi siswa untuk mengikuti pembelajaran akan semakin baik sehingga memberikan pengaruh terhadap peningkatan hasil belajar siswa. Pengelolaan pembelajar di kelas yang menarik akan mampu membangkitkan motivasi belajar siswa, dimana siswa akan tertarik mengikuti pembelajaran apabila pembelajaran sudah dikekola dengan baik.

Menurut Ali (2008:93) "salah satu hambatan yang sering dialami dalam mengajar adalah soal waktu. Seringkali seorang mengajar tidak dapat mengendalikan waktu, Akibatnya bisa menyebabkan materi yang diberikan sudah selesai namun waktu yang tersisa masih panjang, atau sebaliknya waktu sudah habis, namun bahan yang diajarkan belum tuntas. Hal ini membawa pengaruh terhadap proses belajar mengajar yang dilaksanakan". Pengelolaan pembelajaran yang baik harus mampu memanajemen waktu yang ada agar tercapai tujuan pembelajaran yang baik dan mampu diterima oleh siswa itu sendiri. Pengelolaan Pembelajaran merupakan proses untuk mencapai tujuan pembelajaran. Tujuan dari pengelolaan pembelajaran adalah untuk menciptakan proses belajar mengajar dengan mudah direncanakan, diorganisasikan, dilaksanakan dan dikendalikan dengan baik sehingga tercapai tujuan pengajaran yang sudah di rencanakan secara efektif dan efesien.

Untuk mencapai tujuan pembelajaran yang baik diperlukan proses panjang yang dimulai dengan perencanaan, pengorganisasian dan penilaian. Perencanaan meliputi kegiatan menetapkan apa yang ingin dicapai, bagaimana mencapai, waktu dan personel yang diperlukan. Sedang pengorganisasian merupakan pembagian tugas kepada personel yang terlibat dalam usaha mencapai tujuan pembelajaran, 
pengkoordinasian, pengarahan dan pemantauan, terlaksananya semua proses dalam pengelolaan pembelajaran diharapkan nantinya dapat memiliki dampak yang positif terhadap hasil belajar siswa sesuai dengan yang diharapakan oleh guru dan siswa

Berdasarkan hasil observasi awal yang dilakukan oleh peneliti di SMA $\mathrm{N} 2$ Singaraja khususnya siswa kelas XI IPS, motivasi dan hasil belajar siswanya sangat rendah.

Motivasi belajar yang rendah terlihat jelas dari masih banyaknya siswa yang kurang berminat mengikuti pembelajaran, hal ini dapat dilihat dari hasil belajar siswa yang rendah dan masih banyaknya nilai siswa yang belum memenuhi kriteria ketuntasan minimal (KKM). Selain itu motivasi dan hasil belajar yang rendah juga dipertegas oleh guru mata pelajaran ekonomi yang menerangkan bahwa masih terdapat banyak siswa yang sulit untuk memahami pelajaran yang disampaikan dan basih banyak siswa yang tidak memperhatikan pembelajaran yang diberikan.

Segala cara dalam proses pembelajaran sudah dilakukan oleh guru pengajar namun masih banyak siswa yang kurang berminat mengikuti dan menyimak pembelajaran dengan baik. Jika dilihat dari keterangan siswanya sendiri terkait dengan pembelajaran bermacam-macam persepsi atau pendapat yang disampaikan oleh siswa terkait dengan proses pembelajaran yang menyebabkab siswa itu sendiri malas atau enggan mengikuti pembelajaran yang dilakukan di dalam kelas.

Berdasarkan pertimbangan pemikiran dan observasi awal yang dilakukan oleh peneliti maka peneliti mengambil judul "Pengaruh Persepsi Siswa Tentang Pengelolaan Pembelajaran dan Motivasi Siswa Terhadap Hasil Belajar Siswa Kelas XI Mata Pelajaran Ekonomi di SMA N 2 Singaraja".

\section{METODE}

Penelitian ini adalah penelitian kausal. Penelitian kausal adalah suatu penelitian yang dilakukan untuk menggambarkan skema pengaruh yang lebih dalam dari dua atau lebih fakta-fakta dan sifat-sifat objek yang diteliti. Penelitian ini bertujuan untuk melihat pengaruh persepsi siswa tentang pengelolaan pembelajaran dan motivasi belajar siswa terhadap hasil belajar siswa berupa angka atau data.

Berdasarkan rancangan penelitian yang digunakan dalam penelitian ini, maka desain penelitian yang dilakukan akan disajikan dalam bentuk gambar yang tampak seperti gambar 1 sebagai berikut.

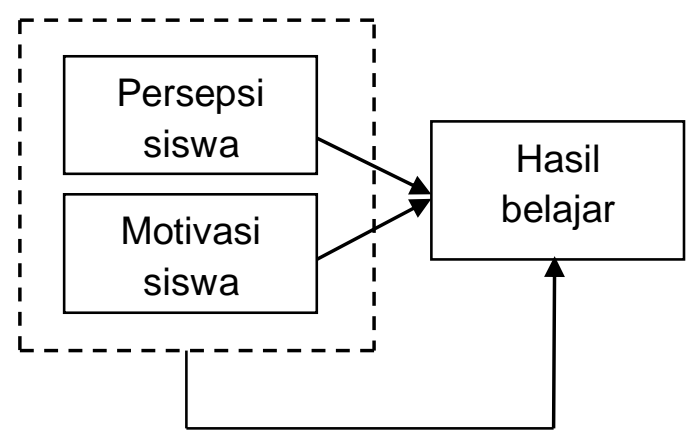

Gambar.1 Rancangan Penelitian

Subyek dari penelitian atau respoden penelitian ini adalah siswa kelas XI IPS SMA N 2 Singaraja dan obyek dari penelitian ini adalah hasil belajar siswa kelas XI IPS pada mata pelajaran ekonomi. Penelitian ini dilaksanakan di di SMA N 2 Singaraja kelas XI Jurusan IPS pada mata pelajaran ekonomi. Penelitian ini menggunakan dua jenis variabel yaitu variabel dependen dan variabel independen. Yang pertama, variabel dependen disebut juga variabel terikat, merupakan variabel yang dipengaruhi atau yang menjadi akibat karena adanya variabel bebas. Variabel dependen dalam penelitian ini adalah hasil belajar siswa $(\mathrm{Y})$. Yang kedua, variabel independen disebut juga variabel bebas, merupakan variabel yang mempengaruhi atau yang menjadi sebab perubahannya atau timbulnya variabel terikat. Variabel independen dalam penelitian ini adalah persepsi (X1) dan motivasi belajar (X2). Adapun jenis data yang digunakan dalam penulisan penelitian ini adalah sebagai berikut. Petama, data kualitatif, yaitu data yang bukan dalam bentuk angka-angka tetapi dalam bentuk pernyataan. Data kualitatif dalam penelitian 
ini berupa persepsi siswa tentang pengelolaan pembelajarn dan motivasi siswa. Data kuantitatif, yaitu data yang berupa angka-angka dan yang kedua, data kuantatif dalam penelitian ini berupa nilai ulangan siswa. Sumber data yang digunakan penulis dalam penelitian ini adalah Data primer, di dalam penelitian ini maka data primernya adalah data berupa persepsi siswa tentang pengelolaan pembelajaran dan motivasi belajar siswa kelas XI untuk meningkatkan hasil belajar. Data primer tersebut diperoleh dari responden melalui angket yang diisi sendiri oleh siswa kelas XI IPS SMA N 2 Singaraja yang dijadikan sampel penelitian. Data Sekunder, dalam penelitian ini, data sekunder diperoleh dari dokumen-dokumen atau data-data yang terdapat pada guru mata pelajaran IPS SMA N 2 Singaraja yang terkait dengan nilai hasil belajar siswa kelas XI SMA N 2 Singaraja Tahun 2016/2017.

Untuk memperoleh data yang lengkap dan akurat, data dikumpulkan dengan menggunakan alat pengumpul data. Di dalam penelitian alat pengumpul data yang digunakan ada 2 yaitu, kuesioner dan dokumentasi. Kuesioner Dalam penelitian ini kuesioner yang digunakan adalah kuesioner tertutup, yang jawabannya sudah disediakan oleh peneliti sehingga responden tinggal memilih. Angket ini menggunakan teknik "skala likert" guna mengukur persepsi siswa tentang pengelolaan pembelajaran dan motivasi siswa. Selain kuesioner yang dijadikan sebagai pengumpul data, dalam penelitian ini juga menggunakan dokumentasi sebagai alat pengumpul data dalam mengetahui dan memperoleh data hasil belajar peserta didik. Adapun populasi dan sample yang digunakan dalam penelitian adalah sebagai berikut. Yang pertama populasi adalah wilayah generalisasi yang terdiri atas subjek atau objek yang mempunyai kualitas dan karakteristik tertentu yang ditetapkan oleh peneliti untuk dipelajari dan kemudian ditarik kesimpulannya. Populasi dalam penelitian ini adalah siswa kelas XI IPS dengan dengan jumlah 105 siswa yang terbagi menjadi 3 kelas dengan distribusi sebagai berikut yang pertama kelas XI IPS 1 berjumlah 35 orang, kelas XI IPS 2 berjumlah 35 orang dan kelas XI IPS 3 berjumlah 34 orang. Yang kedua adalah sample.

Menurut Arikunto (2010:174), "sampel adalah sebagian dari populasi yang ingin diteliti". Bila jumlah populasi besar, dan peneliti tidak mungkin mempelajari semua yang ada pada populasi mialnya karena keterbatasan dana, tenaga, dan waktu maka peneliti dapat menggunakan sampel yang diambil dari populasi itu. Dalam penelitian ini menentukan jumlah sampel maka menggunakan rumus slovin sebagai berikut

$n=\frac{\mathrm{N}}{1+\mathrm{Ne}^{2}}$

Keterangan

$\mathrm{N}=$ ukuran populasi

$\mathrm{n}=$ ukuran sampel

$\mathrm{e}=$ presisi yang ditetapkan (toleransi kesalahan 5\%)

Berdasarkan rumus tersebut jumlah sampel yang akan diteliti adalah sebagai berikut.

$$
\begin{aligned}
n & =\frac{\mathrm{N}}{1+N e^{2}} \\
& =\frac{104}{105 \cdot(0,05)^{2}+1} \\
& =\frac{104}{104 \cdot(0,0025)^{2}+1} \\
& =\frac{105}{1,26} \\
\mathrm{~N} & =83 \text { responden }
\end{aligned}
$$

Dari perhitungan diatas, maka sampel

\begin{tabular}{|c|c|c|c|}
\hline Kelas & $\begin{array}{c}\text { Jumlah } \\
\text { siswa }\end{array}$ & $\begin{array}{c}\text { Perhitunga } \\
\text { n sampel }\end{array}$ & $\begin{array}{l}\text { Jumlah } \\
\text { sampel }\end{array}$ \\
\hline$\underset{1}{\text { XI IPS }}$ & $\begin{array}{c}35 \\
\text { orang }\end{array}$ & $\frac{35}{104} \times 83$ & 28 \\
\hline $\begin{array}{c}\text { XI IPS } \\
1\end{array}$ & $\begin{array}{c}35 \\
\text { orang }\end{array}$ & $\frac{35}{104} x 83$ & 28 \\
\hline $\begin{array}{c}\text { XI IPS } \\
1\end{array}$ & $\begin{array}{c}34 \\
\text { orang }\end{array}$ & $\frac{34}{104} \times 83$ & 27 \\
\hline tota & & & 8 \\
\hline
\end{tabular}
minimal dalam penelitian ini adalah 83 responden. Perhitungan sampel tampak pada Tabel. 1

Tabel .1 Perhitungan sampel 
Teknik penentuan sampel yang dilakukan dala penelitian ini menggunakan metode stratifed ramdem sampling, yaitu pengambilan sampel dari anggota populasi secara acak dan strata proporsional.

Untuk memperoleh data yang lengkap dan akurat, data dikumpulkan dengan alat pengumpul data. $\mathrm{Di}$ dalam penelitian alat pengumpul data yang digunakan ada 2 yaitu, kuesioner dan dokumentasi. Dalam penelitian ini kuesioner yang digunakan adalah kuesioner tertutup, yang jawabannya sudah disediakan oleh peneliti sehingga responden tinggal memilih. Angket ini menggunakan teknik "skala likert" guna mengukur persepsi siswa tentang pengelolaan pembelajaran dan motivasi siswa. Adapun skala yang digunakan yaitu sangat setuju, setuju, kurang setuju, tidak setuju, sangat tidak setuju. Selain kuesioner yang dijadikan sebagai pengumpul data, dalam penelitian ini juga menggunakan dokumentasi sebagai alat pengumpul data dalam mengetahui dan memperoleh data hasil belajar peserta didik. Uji Coba Istrumen, validitas suatu instrument penelitian adalah suatu ukuran yang menunjukkan tingkat-tingkat kevalidan atau kesahan suatu instrumen (Arikunto, 2010:211). Uji Validitas digunakan untuk menunjukkan derajat ketepatanyaitu ketepatan antara data yang sesungguhnya terjadi pada objek dengan data yang dikumpulkan oleh peneliti. Uji validitas instrument menggunakan tehnik analisis korelasi product moment dan menggunakan bantuan SPSS (Statistical Program Social Science) versi 16.0 for windows untuk memudahkan mengolah data peneliti. Menurut Sugiyono (2010:109), "uji validitas diperoleh dengan cara mengkorelasikan setiap skor dengan total skor indikator variabel, kemudian hasil korelasinya dibandingkan dengan nilai kritis pada signifikan 0,05". Syarat minimum instrument penelitian dikatakan valid apabila nilai $T$ hitung $>\mathrm{T}$ tabel.

Uji Reliabilitas, reliabilitas berkenaan dengan pengertian bahwa suatu alat ukur cukup dapat dipercaya untuk digunakan sebagai alat ukur penelitian karena instrument tersebut sudah baik (Arikunto, 2006:178). Untuk menguji reliabilitas alat ukur dalam penelitian ini menggunakan rumus alpha. Instrumen dikatakan reliabel apabila memiliki nilai alpha lebih besar dari 0,60. (Umar, 2002). Rumus yang digunakan adalah sebagai berikut.

$r_{i i}=\left[\frac{k}{(k-1)}\right]\left[1-\frac{\sum \sigma^{2} b}{\sigma_{1}{ }^{2} t}\right]$

Keterangan

Rii = Koefisien reliabilitas instrument

$\mathrm{k}=$ Banyaknya item pernyataan

$\sum \sigma^{2} \mathrm{~b}=$ Jumlah variasi item

$\sum \sigma_{1}^{2} t=$ Variasi total

Uji reliabilitas dilakukan setelah uji validitas, sehingga yang akan diukur hanyalah item pernyataan yang sudah valid saja. Pengukuran reliabilitas ini menggunakan bantuan SPSS 16,0 for windows. Instrumen dikatakan reliabel apabila $p$-value $x y<a ́$ a 0,05 . Setelah dilakukan uji validitas dan uji reabilitas maka dilanjutkan dengan menganalisis data.

Adapun Tehnik analisis data yang digunakan dalam penelitian ini adalah Analisis regresi linier berganda digunakan untuk menentukan besarnya hasil belajar (Y) yang disebabkan persepsi siswa tentang pengelolaan pembelajaran $\left(X_{1}\right)$, dan motivasi belajar $\left(X_{2}\right)$. Model pengaruh hasil belajar dengan variabel-variabel tersebut dapat disusun dalam fungsi atau persamaan sebagai berikut. (Ghozali, 2005).

$\mathrm{Y}=\alpha+\mathrm{b}_{1} \mathrm{x}_{1}+\mathrm{b}_{2} \mathrm{x}_{2}+\mathrm{e}$

Keterangan :

$\mathrm{Y}=$ Hasil Belajar Siswa

$\alpha \quad=$ Konstanta

$\mathrm{x}_{1}=$ Variabel persepsi tentang pengelolaan pembelajaran

$\mathrm{x}_{2} \quad=$ Variabel Motivasi belajar

$b_{1}, b_{2},=$ Koefisien regresi variabel $x_{1}$ dan $x_{2}$

$\mathrm{e} \quad=$ Kesalahan atau standard error 
Sebelum dilakukan analisis data terlebih dahulu dilakukan uji prasyaratan untuk mengetahui apakah model regresi layak untuk diteliti. Uji asumsi klasik adalah persyaratan analisis yang harus dipenuhi pada analisis regresilinier berganda. Menurut Ghozali (2010:147) terdapat uji asumsi klasik yangharus diujikan adalah sebagai beriku. Uji Asumsi Klasik yang pertama adalah uji normalitas

Uji normalitas bertujuan untuk menguji apakah dalam model regresi, variabel dependen, variabel independen, atau keduanya mempunyai distribusi normal atau tidak (Ghozali, 2010:147). Dasar pengambilan keputusan berdasarkan probabilitas. Jika probabilitas $>0,05$ maka data penelitian berdistribusi normal. Dilanjutkan dengan uji multikolonieritas, uji multikolineritas bertujuan untuk menguji apakah model regresi ditemukan adanya korelasi antar variabel bebas (independen). Model regresi yang baik seharusnya tidak terjadi korelasi diantara variabel independen. Uji multikolinieritas dapat dilihat dari nilai tolerance dan lawannya, dan Variance Inflancion Factor (VIF). Nilai cut off yang umum dipakai untuk menunjukkan adanya multikolonieritas adalah nilai Tolerance $<0,10$ atau sama dengan nilai VIF < 10 (Ghozali, 2010:105). Dan yang yang ketiga adalah uji heteroskedastisitas.

Uji heteroskedastisitas bertujuan untuk menguji apakah dalam model regresi terjadi ketidaksamaan varian dari residual satu pengamatan ke pengamatan yang lain. Jika varian dari residual satu pengamatan ke pengamatan yang lain tetap, maka disebut Homoskedastisitas dan jika berbeda disebut Heterokedastisitas. Untuk mengetahui adanya hetersokedastisitas dapat dilihat dengan melihat Grafik Plot antara nilai prediksi variabel terikat (dependen) dengan nilai residualnya. Cara mendeteksi ada tidaknya heteroskedastisitas adalah dengan melihat ada tidaknya pola tertentu pada grafik Scatter plot dengan menggunakan program SPSS, dimana sumbu $Y$ adalah $Y$ yang telah diprediksi, dan sumbu $X$ adalah residual. Dasar dalam pengambilan keputusan antara lain: Yang pertama jika ada pola tertentu, seperti titik-titik yang ada membentuk suatu pola tertentu yang teratur (bergelombang, melebar, kemudian menyempit), maka terjadi Heteroskedastisitas. Yang kedua jika tidak ada pola yang jelas, serta titik-titik menyebar di atas dan di bawah angka 0 pada sumbu $\mathrm{Y}$, maka tidak terjadi Heteroskedastisitas (Ghozali, 2010:139).

Setelah melakukan uji asumsi klasik dan data didistribusi normal maka akan dilanjutkan dengan uji hipotesis. Uji hipotesis yang dilakukan pertama adalah Uji Signifikansi Simultan (Uji F). Menurut Ghozali (2011:98) uji statistik $F$ pada dasarnya menunjukkan apakah semua variabel bebas yang dimaksudkan dalam model mempunyai pengaruh secara simultan terhadap variabel dependen. Pengujian dilakukan dengan menggunakan significance level 0,05 ( $\alpha=5 \%)$. Ketentuan penerimaan atau penolakan hipotesis adalah sebagai berikut. Yang pertama jika nilai signifikan > 0,05 maka Ho diterima (koefisien regresi tidak signifikan). Ini berarti bahwa secara simultan kedua variabel independen tersebut tidak mempunyai pengaruh yang signifikan terhadap variabel dependen. Yang kedua jika nilai signifikan < 0,05 maka Ho ditolak (koefisien regresi signifikan). Ini berarti secara simultan kedua variabel independen tersebut mempunyai pengaruh signifikan terhadap variabel dependen.

Setelah melalakukan uji $\mathrm{F}$ maka selanjutnya dilakukan Uji Signifikansi Pengaruh Parsial (Uji t). Uji t digunakan untuk menguji signifikansi hubungan antara variabel $X$ dan $Y$, apakah variabel $X_{1}$ dan $X_{2}$ (persepsi siswa tentang pengelolaan pembelajaran dan motivasi belajar) benarbenar berpengaruh terhadap variabel $Y$ (hasil belajar) secara terpisah atau parsia. Pengujian dilakukan dengan menggunakan significance level $0,05(\alpha=5 \%)$. Penerimaan atau penolakan hipotesis dilakukan dengan kriteria sebagai berikut. Yang pertama jika nilai signifikansi > 0,05 maka Ho ditolak (koefisien regresi tidak signifikan). Ini berarti bahwa secara parsial variabel independen tersebut tidak mempunyai pengaruh 
signifikan terhadap variabel dependen. Yang kedua jika signifikan $<0,05$ maka Ho diterima (koefisien regresi signifikan). Ini berarti secara parsial variabel independen tersebut mempunyai pengaruh yang signifikan terhadap variabel dependen. Setelah melakukan uji $\mathrm{F}$ dan uji t maka akan dilakukan uji Koefisien Determinasi $\left(R^{2}\right)$. Koefisien determinasi $\left(R^{2}\right)$ dimaksudkan untuk mengetahui tingkat ketepatan paling baik dalam analisis regresi dimana hal yang ditujukan oleh besarnya koefisien determinasi $\left(\mathrm{R}^{2}\right)$ antara 0 sampai dengan 1 . Koefisien determinasi $\left(R^{2}\right)$ nol variabel independen sama sekali tidak berpengaruh terhadap variabel dependen. Apabila koefisien determinasi semakin mendekati satu, maka dapat dikatakan bahwa variabel independen berpengaruh terhadap variabel dependen, selain itu koefisien determinasi $\left(\mathrm{R}^{2}\right)$ dipergunakan untuk mengetahui presentase perubahan variabel tidak bebas ( $Y$ ) yang disebabkan oleh variabel bebas $(X)$.

\section{HASIL DAN PEMBAHASAN Hasil Penelitian}

Pada bagian hasil penelitian akan disajikan data mengenai pengaruh persepsi siswa tengtang pengelolaan pembelajaran dan motivasi belajar siswa terhadap hasil belajar siswa kelas XI IPS di SMA N 2 Singaraja. Sebelum data hasil penelitian dipaparkan, terlebih dahulu akan disajikan hasil pengujian validitas, reliabilitas dan uji asumsi klasik sebagai prasyarat analisis. Sebelum melakukan analisis regresi peneliti juga melakukan uji validitas untuk mengukur tingkat kevalidan atau kesahan suatu instrument. Untuk mengetahui item pertanyaan yang valid dilihat dari nilai yang terletak pada kolom Corrected Item-Total Correlation. Kriteria sebuah item pertanyaan dikatakan valid jika nilai korelasi $>$ korelasi tabel, dimana jumlah responden 30 orang maka nilai korelasi tabel menunjukkan angka 0.361 jika kriteria sudah dipenuhi berarti pertanyaan sudah cukup valid. Hasil dari uji validitas semua variabel yang diajukan kepadan 30 orang responden tertera pada lampiran.

Berdasarkan hasil uji validitas diatas dapat disimpulkan bahwa 24 butir soal yang memiliki nilai korelasi $>0.361$ maka pernyatan soal dapat digunakan dan 6 butir soal memiliki nilai korelasi $<0.361$ maka pernyataan butir soal dihilangkan. Untuk hasil SPSS uji validitas dapat dilihat di Lampiran.Untuk menguji instrument penelitian ini, peneliti menggunakan program SPSS 16 sebagai alat analisisnya. Menurut Nunnally dalam Ghozali (2013:48) menyebutkan bahwa suatu konstruk atau variabel dikatakan reliabel jika memberikan nilai cronbach alpha>0.70. Berikut ini adalah hasil output SPSS dari analisis reliabilitas instrument penelitian yang dapat dilihat pada tabel. 2

Tabel 2. Hasil Analisis Uji Reliabilitas

Persepsi Siswa tentang Pengelolaan Pembelajaran

\begin{tabular}{rr}
\hline \multicolumn{2}{c}{ Reliability Statistics } \\
Cronbach's \\
Alpha & N of Items \\
.911 & 13 \\
\hline
\end{tabular}

\section{Berdasarkan hasil perhitungan maka dapat disimpulkan instrument penelitian variabel persepsi adalah reliabel karena nilai Cronbach's Alpha> 0.70 yaitu 0.911.}

Tabel. 3 Hasil Analisis Uji Reliabilitas Motivasi Belajar

Reliability Statistics
Cronbach's
$\begin{array}{cr}\text { Alpha } & \text { N of Items } \\ .760 & 11\end{array}$

Berdasarkan hasil perhitungan maka dapat disimpulkan instrument penelitian variabel lingkungan teman sebaya adalah reliabel karena nilai Cronbach's Alphas 0.70 yaitu 0.760 . Setelah melakukan uji validitas dan uji reliabilitas data yang sudah diuji sudah dinyatakan berdistribusi normal dengan dilakukan uji asumsi klasik yaitu Uji Normalitas, Uji Multikolinieritas dan Uji Heteroskedastisitas. Setelah melakukan uji asumsi dan data didistribusi normal maka dilanjutkan dengan uji $\mathrm{t}$ yaitu Pengaruh persepsi siswa tentang pengelolaan pembelajaran terhadap hasil belajar siswa. 
Hasil output dari pengujian ini dapat dilihat

pada tabel 4 .

Tabel 4. Hasil Uji t Persepsi Siswa tentang Pengelolaan Pembelajaran

\begin{tabular}{|c|c|c|c|c|c|c|}
\hline \multirow[b]{3}{*}{ Model } & & \multicolumn{3}{|c|}{ Coefficients $^{a}$} & \multirow[b]{3}{*}{$\mathrm{t}$} & \multirow[b]{3}{*}{ Sig. } \\
\hline & & \multicolumn{2}{|c|}{$\begin{array}{l}\text { Unstandardized } \\
\text { Coefficients }\end{array}$} & \multirow{2}{*}{$\begin{array}{c}\text { Standardized } \\
\text { Coefficients } \\
\text { Beta }\end{array}$} & & \\
\hline & & $\mathrm{B}$ & Std. Error & & & \\
\hline 1 & (Constant) & 9.671 & .444 & & 17.923 & .000 \\
\hline & $\mathrm{X} 1$ & -.061 & .017 & -.285 & 6.452 & .009 \\
\hline
\end{tabular}

a. Dependent Variable: $Y$

\section{Berdasarkan hasil perhitungan} terlihat nilai signifikansi pada variabel persepsi siswa 0.009 sehingga nilai sig < 0.05 atau nilai $0.009<0.05$ maka $H_{a}$ diterima dan $H_{0}$ ditolak. Maka dapat disimpulkan bahwa variabel persepsi siswa
(X1) memiliki pengaruh yang signifikan terhadap hasil belajar (Y). Pengaruh motivasi belajar terhadap hasil belajar hasil output pengujian ini dapat dilihat pada tabel 5.

Tabel 5. Hasil Uji t Motivasi Belajar Terhadap Hasil Belajar

\begin{tabular}{|c|c|c|c|c|c|c|}
\hline \multicolumn{7}{|c|}{ Coefficients $^{a}$} \\
\hline \multirow{2}{*}{\multicolumn{2}{|c|}{ Model }} & \multicolumn{2}{|c|}{$\begin{array}{l}\text { Unstandardized } \\
\text { Coefficients }\end{array}$} & \multirow{2}{*}{$\begin{array}{c}\text { Standardized } \\
\text { Coefficients } \\
\text { Beta } \\
\end{array}$} & \multirow[b]{2}{*}{$\mathrm{t}$} & \multirow[b]{2}{*}{ Sig. } \\
\hline & & $\mathrm{B}$ & Std. Error & & & \\
\hline \multirow[t]{2}{*}{1} & (Constant) & 9.671 & .444 & & 17.923 & .000 \\
\hline & $\mathrm{X} 2$ & .029 & .023 & .200 & 2.420 & .021 \\
\hline
\end{tabular}

a. Dependent Variable: $Y$

Berdasarkan hasil perhitungan terlihat nilai signifikansi pada variabel lingkungan teman sebaya memiliki nilai signifikansi 0.021 sehingga nilai sig $<0.05$ atau nilai $0.021<0.05$ maka $H_{a}$ diterima dan $H_{0}$ ditolak.
Dapat disimpulkan bahwa variabel motivasi belajar (X2) memiliki pengaruh yang signifikan terhadap hasil belajar (Y). Hasil uj regresi pengaruh persepsi siswa dan motivasi belajar terhadap hasil belajar siswa dapat dilihat pada tabel 6 .

tabel 6. Hasil Uji Regresi

\begin{tabular}{|c|c|c|c|c|c|c|}
\hline \multicolumn{7}{|c|}{ Coefficients $^{a}$} \\
\hline & & $\begin{array}{r}\text { Unstand } \\
\text { Coeffi }\end{array}$ & $\begin{array}{l}\text { ardized } \\
\text { cients }\end{array}$ & $\begin{array}{l}\text { Standardized } \\
\text { Coefficients }\end{array}$ & & \\
\hline \multicolumn{2}{|c|}{ Model } & B & Std. Error & Beta & $\mathrm{t}$ & Sig. \\
\hline \multirow[t]{3}{*}{1} & (Constant) & 9.671 & .444 & & 17.923 & .000 \\
\hline & Persepsi siswa & -.061 & .017 & -.285 & 6.452 & .009 \\
\hline & Motivasi belajar & .029 & .023 & .200 & 2.420 & .021 \\
\hline
\end{tabular}

a. Dependent Variable: hasil belajar 
Berdasarkan uji regresi antara persepsi siswa tentang pengelolaan pembelajaran dan motivasi belajar siswa terhadap hasil belajar siswa terbentuk model regresi sebagai berikut.

$\hat{Y} \quad: 9.671-0.061 X 1+0.029 X 2$

Berdasarkan persamaan regresi di atas diartikan jika jika koefision persepsi siswa tentang pengelolaan pembelajaran (X1) turun satu satuan, maka nilai hasil belajar siswa akan turun sebesar -0.061 . jika nilai motivasi belajar (X2) naik satu satuan maka nilai hasil belajar siswa $(\mathrm{Y})$ akan naik sebesar 0,021.

Sebelum melakukan uji hipotesis dan uji regresi data yang akan diuji sudah lulus uji asumsi klasik diataranya adalah.

Yang pertana, uji normalitas dengan nilai signifikan 0,301 >0,05 yang berarti data yang akan diujikan sudah berdistribusi normal dan layak untuk diujikan. Yang kedua, Uji multikoleniaritas variabel persepsi siswa tentang pengelolaan pembelajaran dan motivasi belajar samasama memilikia nilai tolerance 0,315 yang bebih dari 0,1 dan nilai VIF 3,175 yang kurang dari 10 yang berarti bahwa data yang akan diuji tidak terjadi multikolinearitas, yang ketiga, Uji heteroskedastisitas variabel persepsi siswa tentang pengelolaan pembelajaran dengan nilai signifikan $0.447>0.05$ dan variabel motivasi belajar dengan nilai signifikan $0,891>0,05$ yang berarti data variabel persepsi siswa tentang pengelolaan pembelajaran dan motivasi siswa tidak terjadi heteroskedastisitas. Setelah melakukan uji regresi secara parsial kemudian dilanjutkan dengan uji koefision determinasi untuk mengetahui seberapa besar pengaruh persepsi siswa tentang pengelolaan pembelajaran dan motivasi belajar secara simultan terhadap hasil belajar dapat dilihat pada tabel 7 .

Tabel 7. Hasil Uji Koefision Determinasi (Adjusted $R$ Square)

\begin{tabular}{lrrrr}
\hline Model & $\mathrm{R}$ & $\mathrm{R}$ Square & Adjusted R Square & Std. Error of the Estimate \\
\hline 1 & $.164^{\mathrm{a}}$ & .227 & .203 & .2629
\end{tabular}

a. Predictors: (Constant), X1,X2

Berdasarkan anlisis pada tabel 7. menunjukkan bahwa besaranya pengaruh persepsi siswa tentang pengelolaan pembelajaran dan motivasi belajar terhadap hasil belajar sebesar 0,203 yang berarti sumbangan pengaruh persepsi (X1) dan motivasi belajar (X2) sebesar 203\% terhadap hasil belajar siswa $(\mathrm{Y})$.

\section{Pembahasan}

Hasil penelitian menunjukkan bahwa terdapat pengaruh yang signifikan antara persepsi siswa tentang pengelolaan pembelajaran terhadap hasil belajar siswa kelas XI IPS di SMA 2 Singaraja, terdapat pengaruh yang signifikan motivasi belajar terhadap hasil belajar siswa kelas XI IPS di SMA N 2 Singaraja, dan terdapat pengaruh persepsi siswa tentang pengelolaan pembelajaran dan motivasi belajar siswa secara simultan mempengaruhi hasil belajar siswa kela XI IPS di SMA N 2 Singaraja.

Persepsi siswa terntang pengelolaan pembelajaran dan motivasi belajar siswa memberikan konstribusi terhadap hasil belajar mahasiswa yang relatif kecil, hal ini menunjukkan bahwa siswa harus lebih memperhatikan dan memahami setiap proses pembelajaran yang berlangsung dan mampu berperan langsung secara aktif dengan proses pembelajaran. Untuk mengomptimalkan persepsi siswa tentang pengelolaan pembelajaran maka diperlukan peran seorang guru dalam mengelola pembelajaran dengan baik agar siswa mampu mencerna dan memahami setiap pembelajaran yang disampaikan dan seorang guru perlu mengoptimalkan kodisi kelas agar siswa dengan tenang dan 
nyaman dalam mengikuti proses pembelajaran.

Persepsi siswa yang baik terhadap proses pembelajaran atau pengelolaan pembelajaran dikelas akan membantu siswa lebih tertarik terhadap pembelajaran dan lebih memudahkan siswa memahami materi pembelajaran, namun untuk menumbuhkan persepsi siswa yang baik terhaadap pembelajaran harus didukung dengan cara guru mengelola pembelajaran tersebut seperti misalnya dengan menggunakan model pembelajaran yang menarik sehingga siswa tertarik untuk mengikuti pembelajaran. Selain itu guru diharapkan dapat berinteraksi dengan baik dengan siswanya agar proses belajar mengajar menjadi lebih santai dan siswa menjadi lebih nyaman menerima pembelajaran. Dengan tumbuhnya persepsi siswa yang baik terhadap pembelajaran maka akan menumbuhkan motivasi siswa untuk belajar dan mengikuti pembelajaran yang nantinya akan berpengaruh terhadap hasil belajar yang lebih baik lagi.

Motivasi belajar sebagai faktor eksternal yang mempengaruhi hasil belajarsiswa. Dorongan dari orang tua, teman sebaya, dan lain sebagainya akan mampu meningkatkan keinginan atau kemapuan siswa untuk belajar. Untuk menumbuhkan motivasi belajar siswa di dalam kelas harus didukung guru dengan cara memperbaiki model pembelajaran menjadi lebih menarik, memberikan penghargaan terhadap siswa yang aktif, memberikan perhatian yang sama kepada setiap siswa maka akan menumbuhkan motivasi siswa untuk belajar dan mengikuti pembelajaran dengan baik. Dengan adanya persepsi siswa yang baik tentang pengelolaan pmebelajara dan juga motivasi belajar dari siswa itu sendiri akan sangat berpengaruh terhadap hasil belajara yang akan dicapai oleh siswa itu sendiri, karena dengan persepsi yang baik dan motivasi belajar akan menumbuhkan keinginan siswa untuk melajar di dalam kelas maupun di luar kelas, dengan siswa belajar dengan baik akan membantu siswa mendapatkan nilai yang memuaskan pada setiap mata pelajaran yang dipelajari.

\section{SIMPULAN DAN SARAN}

Berdasarkan hasil penelitian, maka dapat ditarik kesimpulan sebagai berikut.

Yang pertama terdapat pengaruh positif persepsi siswa tentang pengelolaan pembelajaran terhadap hasil belajar siswa kelas XI IPS SMA N 2 Singaraja. Siswa yang memiliki persepsi yang baik terhadap pengelolaan pembelajaran akan dapat mengikuti pembelajaran dengan baik pula dan akan berpengaruh juga terhadap hasil belajar yang lebih baik. Yang kedua, terdapat pengaruh positif motivasi belajar terhadap hasil belajar siswa Kelas XI IPS di SMA N 2 Singaraja. Semakin besar motivasi belajar siswa maka hasil belajar yang didapat akan semakin tinggi juga, yang ketiga, terdapat pengaruh positif persepsi siswa tentang pengelolaan pembelajaran dan motivasi belajar terhadap hasil belajar siswa kelas XI IPS di SMA N 2 Singaraja. Maka hal ini mengandung makna apabila siswa diberikan pelajaran sesuai dengan proses pembelajaran yang menarik dan menyenangkan mereka akan lebih mudah memahami. Berdasarkan hasil penelitian yang telah dilakukan, adapun beberapa saran yang dapat diberikan sebagai berikut.

Bagi Siswa, Siswa hendaknya dapat mengikuti kegiatan pembelajaran dengan baik. Hal ini diharapkan akan meningkatkan minat belajar siswa, sehingga dari diri siswa dapat menumbuhkan persepsi yang positif pada setiap kegiatan pembelajaran. Bagi guru, Guru sebagai tenaga pendidik harus mampu mengelola pembelajaran sebaik mungkin agar siswa tertarik dengan pembelajaran yang dilakukan. Guru harus mampu menyampaikan pembelajaran dengan baik seperti dengan menggunakan model dan media pembelajaran yang menarik, mengadakan game atau kuis dapat menumbuhkan motivasi siswa untuk mengikuti pembelajaran dan menanamkan persepsi yang positif terhadap kegiatan pembelajaran yang dilakukan. Bagi Peneliti, peneliti lain diharapkan mampu memanfaatkan dan mengembangkan hasil penelitian ini dan menyempurnakannya lagi sebagai satu bentuk refrensi pembelajaran 
p-ISSN : 2599-1418

e-ISSN : 2599-1426

dan dapat mengembangkan hasil penelitian ini dalam ruang lingkup yang lebih luas.

\section{DAFTAR PUSTAKA}

Ali, M. (2008). Guru Dalam Proses Belajar Mengajar. Bandung; Sinar Baru Algensindo

Arikunto, S. 2010. Manajemen Penelitian. Jakarta : Rineka Cipta

2016. Prosedur Penelitian: Suatu Pendekatan Praktek, Edisi Revisi. Jakarta : Rineka Cipta

Djamarah. 2002. Prestasi Belajar dan Kompetensi Guru. Surabaya: Rineka Cipta

Donald Mc. 2012. Motivasi Dalam Pendidikan. Jakarta: PT Indeks

Ghozali, Imam. 2005. Aplikasi Analisis Multivariate dengan Program SPSS. Semarang: Badan Penerbit Salemba Empat.

2010. Aplikasi Analisis Multivariate dengan Program IMB SPSS 19. Semarang: Badan Penerbit Fakultas Ekonomi Universitas Diponegoro.

2011. Aplikasi Analisis Multivariate dengan Program SPSS . Semarang: Badan Penerbit Fakultas Ekonomi Universitas Diponegoro

2013. Aplikasi Analisis Multivariate dengan Program SPSS. Edisi Ketujuh. Semarang: Badan Penerbit Fakultas Ekonomi Universitas Diponegoro

Miftah, Toha. 2003. Perilaku Organisasi Konsep Dasar Dan Aplikasinya. Jakarta: Grafindo Persada

Sanjaya, W. 2009. Kurikulum dan Pembelajaran (teori dan praktik pengembangan KTSP). Jakarta: Kencana. Prenada Media Gruop

Slameto. 2003. Prosedur Belajar Mengajar. Jakarta: Bumi Aksara
Jurnal Pendidikan Ekonomi Undiksha

Volume 10 No. 2 Tahun 2018

Slameto. 2010. Belajar dan Faktor-faktor yang Mempengaruhinya. Jakarta: Rineka Cipta

Sudjaya. 2002. Dasar-dasar Proses Belajar Mengajar. Bandung: Sinar Baru

Sugihartono .2007. Psikologi Pendidikan. Yogyakarta. UNY Press

Sugiono. 2010. Statistik Untuk Penelitian. Bandung: Alfabeta

UU No. 20 Tahun 2003. Sistem Pendidikan Nasional.

Umar, Husein. 2002. Metode Penelitian Untuk Skripsi dan Tesis Bisnis. Jakarta: Rajawali Press

Walgito, Bimo. 2010. Pengantar Psikologi Umum. Surabaya: Bina IImu 